\title{
HOME LAB AS A STRATEGY FOR MEANINGFUL LEARNING OF MICROBIOLOGY DURING COVID- 19 PANDEMIC
}

\author{
López ALS*, Navarro-López DE and Castañeda-Sedano J \\ Tecnologico de Monterrey,Campus Guadalajara, Mexico
}

\begin{abstract}
Meaningful learning allows students to enrich their knowledge as well as achieve personal growth. For this purpose, it is necessary to identify and address the needs and motivations of students, this can be achieved by implementing novel strategies in the teaching-learning process. Since March 2020, due to the SARS-Cov2 pandemic, face-toface lectures were suspended in all Mexican educational institutions; this situation forced educators to make drastic changes in teaching dynamics; being the most challenging classes that required the use of laboratories. In the present study this challenge is addressed. The aim of this research was to implement at-home laboratories, during the COVID-19 pandemic, to develop essential microbiology laboratory (ML) competencies and increase student motivation. Didactic intervention was conducted during the spring semester of 2020 with biotechnology students from four ML courses. The methodology was based on using at-home laboratories for their final course project. Students worked in teams to design an experimental strategy, based on knowledge obtained through virtual laboratories, and managed to conduct these experiments with the use of materials found in each student's home; they then presented their results where competencies and learning objectives were evaluated. Descriptive statistics, including the analysis of variance and Tukey test with a confidence level of $95 \%$ to ensure significant differences, were used to analyze and measure the obtained data trends regarding ML competencies acquisition. Results showed no significant differences in the conceptual understanding of the evaluated subject after the implementation of the stated educational strategy, as part of the digitization of the course provided during pandemic confinement; these observations allow us to conclude that the implementation objective for compliance with the ML competencies was effectively achieved.
\end{abstract}

Keywords: Home laboratory, Microbiology, Educational innovation, Higher Education

\section{Introduction}

In December 2019, the COVID-19 disease caused by the SARS-CoV-2 virus emerged in China and spread across the world resulting in the closure of all educational institutions in Mexico. Schools were forced to implement innovative teaching strategies and cutting-edge technologies to ensure academic continuity. Tec de Monterrey University then implemented the Flexible Digital Model (DFM) to guarantee this. Within the framework of the DFM it was necessary to implement learning strategies that combined didactics with technology, so in the Microbiology Laboratory (ML) learning activities were developed with the use of simulators and virtual laboratories. In addition, to promote meaningful learning and competence development, an integrative activity was carried out, consisting of a "Home Lab" where students used materials available at home to conduct simple experiments of microbiology 
with the intention of strengthening the learning of basic microbiology techniques as well as collaborative work. The "home lab" allowed students to put into practice what they learn in the course and helped the teacher identify the strengths and areas of opportunity of the strategy used to implement the course.

Microbiology is the science responsible for the study of microscopic organisms (cellular and subcellular), mainly those that are below the resolution power of the human eye (Rojas-Treviño, 2011). It is one of the bases for the training of professionals in several areas such as Bioengineering, hence the importance of carrying out effective learning strategies that guarantee the development of competencies in this area during the contingency time.

In order to achieve meaningful learning, it is necessary to identify and pay attention to the diversity of interests, needs and motivations of students in relation to the teaching-learning process, as well as to seek new alternatives for selection, organization and distribution of knowledge associated with the design and promotion of learning strategies (Díaz-Barriga and Hernández-Rojas, 2010). It was found that most of the students expressed the need to put into practice some of the topics learned in simulators and virtual laboratories so they chose to strengthen the strategy by implementing the activity of "home laboratory". Several authors have postulated that it is through the realization of significant learning that students construct meanings that enrich their knowledge of the physical and social world, thus enhancing their personal growth (Díaz-Barriga and Hernández-Rojas, 2010).

For Vygotsky, the social context influences learning, it has a profound influence on how people think and what they think (Martínez-Narváez, 2008). Hence the importance of considering the situation of isolation of the students and showing empathy for the development of the proposed activity considering the great limitations that some of them might have.

Burga (2004) states that one of the ideas most widely disseminated by the new pedagogical school is to promote the participation of the student in the learning process making use of techniques and dynamics aimed at developing the contents of the class seeking to motivate and promote the interest of students.

The activity of the "home laboratory" was developed in a collaborative way. The importance of collaborative work lies in the need for people to unite their strengths to face the challenges of work, community life and continuous innovation (Vázquez et al., 2017) and it is through this that they identify, interpret and solve problems of the context together, achieving a greater scope than is achieved individually (Hernández et al., 2015). In addition, collaboration is key to develop the talent of people, since those with more skills development become role models for others and the transfer of knowledge and skills is promoted (Loan-Clarke and Preston, 2002).

Obtaining the knowledge and skills required by the ML without having physical spaces, materials and conditions normally found in the laboratory was a challenge for the students. This paper describes the experience with Bioengineering students from 4 groups of the ML class using as a tool the "Home Laboratory" with the intention that students acquire meaningful learning of basic microbiology techniques and encouraging collaborative work. 
The aim of this study was to implement at-home laboratories during the COVID-19 pandemic, in order to develop essential ML competencies and increase student motivation. This educational innovation offers a flexible and personalized learning experience.

\section{Methodology}

In order to ensure the academic continuity of the school programs of Tec de Monterrey University during the suspension of face-to-face courses derived from COVID-19 pandemic, students began remote activities on March 23, 2020.

The didactic intervention was conducted during the spring semester of 2020 with biotechnology students from four ML courses. The methodology was based on the incorporation of innovative and challenging activities that promoted the acquisition of practical skills, through collaborative and remote work. The innovation implementation process was carried out in 3 stages.

\section{Stage 1. Virtual laboratories.}

Laboratory practices were adapted to the virtual model by a group of professors who teach the subject at National level. To begin with the remote model, the new class dynamics and rules were presented to the students, where for each session the following activities were planned:

1. In the first minutes of class, individual quizzes associated with the subject of practice were applied. The teacher could rely on interactive or gamification online platforms such as Kahoot, Socrative or Quizzi.

2. The teacher explained the objective of the practice and gave instructions for the use of the virtual simulator. The students carried out the experiments remotely using videos and interactive platforms such as: Jove, Biorender, Virtual interactive bacteriology laboratory.

3. Students met virtually in breakout rooms via zoom to discuss and report the results including the analysis of practical cases.

\section{Stage 2. Laboratory at home}

Considering the knowledge acquired in remote laboratories, students were asked to design a work plan for the development of a series of experiments at home where they could apply in a practical way the skills associated with the microbiology laboratory for their final course project.

Students worked in teams and to promote flexible learning and creativity, each team proposed their own protocol which could be adequate considering the resources and materials that each student had at home. The types of experiments performed in the home laboratory included the following parameters:

- Selection of the sample and application of the corresponding sterility and asepsis techniques

- Preparation of homemade culture media, justifying the use of each ingredient and the quantities. The selection of a certain type of culture media depends on the type of microorganism to be isolated 
- Application of the most common microorganism isolation techniques. These criteria included the design and adaptation of homemade instruments for this activity.

- Macroscopic identification of microorganism and colony morphology.

- Experimental variations according to the type of microorganism to be isolated. This included the use of selective media, temperature or $\mathrm{pH}$ variations, incorporation of micro and macronutrients, fermentations, use of antibiotics, immobilization of microorganisms.

It is important to mention that all of the above was done exclusively with the materials that each student had at home.

\section{Stage 3. Assessment of learning and competencies}

Students executed the proposed protocol, analyzed the results and presented their findings at the end of the semester in a plenary session. Different types of resources were used such as video or poster. After each presentation, a question session was followed. The projects were evaluated by means of a rubric by faculty members, where the degree of fulfillment of the subject learning objectives and competencies development was considered.

In addition, co-evaluations and self-evaluations were applied to assess collaborative work. A Google form was used as a data collection instrument to assess various criteria associated with the understanding of fundamentals topics of the ML, the development of strategic skills for the management of digital platforms, the strategies for the execution of experimental activities at home, student motivation and the degree of acceptance of the activity. The assessment included a qualitative and quantitative approach.

With the data obtained from the evaluation, an analysis of variance was performed using the procedures of statistical package $\mathrm{R}$ studio (v1.2.5033). For the separation between means, an analysis was performed using the Tukey test, with a significance level of $95 \%$. The homogeneity of variance between the treatments was checked using the Barlett test and the normal distribution of the data was determined with the Shapiro Wilk test.

\section{Results}

The results of the surveys were obtained by the students in which five parameters related to the understanding of the fundamentals of the subjects and the use of virtual simulators as assistants were analyzed. In the first parameter, the acquisition of knowledge associated with sterilization and disinfection was evaluated, the second to the knowledge of the culture media, the third to the understanding of the microorganism isolation process, the fourth on the macroscopic characterization of microorganisms, the fifth on understanding the course and basic experimental principles of microbiology.

Regarding the understanding of the fundamental concepts of microbiology, a satisfactory response was observed when answering with values higher than 8 by most of the students, where 1 corresponds to No understanding and 10 total understanding (Figure 1). 
We first assessed homogeneity of variances and normal distribution of our data. Then, to determine if the understanding of at least one of the evaluated parameters was not achieved, a multifactorial analysis of variance was carried out with a confidence level of $95 \%$. The results show that the students were able to successfully understand each of the mentioned parameters given that there were no significant differences with $\mathrm{p}$ values greater than 0.05 (Table 1)

The understanding of the fundamentals of microbiology was evaluated during the implementation of the laboratory simulators used in the different digital platforms. It was observed that most of the students managed to understand the concepts by implementing the virtual platforms as assistants with values greater than 7.45 , where 1 corresponds to no comprehension and 10 total comprehension (Figure 2)

Regarding the evaluation of the level of satisfaction with the experimental activities carried out at home during pandemic by the students, the results were favorable when observing that $62.3 \%$ of the students considered totally adequate, $29.5 \%$ very adequate and $8.2 \%$ adequate corresponding to the 38, 18 and 5 opinions about the implementation of the model for the fulfillment of the objectives of the course (Figure 3 )

Finally, the opinion of the students on the development of experimental projects at home with homemade elements was consulted in order to generate an improvement plan in the implementation of this study method during pandemic (Table 2). Most positive opinions were obtained on the acquisition of knowledge and the improvement in the execution of the experimental activities. Regarding unsatisfactory opinions, they are focused more on the lack of adequate conditions for experimentation and the lack of elements to be able to execute them.

\section{Discussion}

The COVID pandemic has caused major changes in education systems worldwide. All educational levels were forced to switch to an online teaching modality. In March 2020 teachers were challenged to convert their courses to a digital format. This new educational format was especially difficult to implement in practical courses since they are aimed at developing practical skills (Dhawan, 2020). In this context major concern among microbiology educators is our inability to offer a typical in-person microbiology laboratory experience (Noel et al., 2020). For this reason, implementing laboratory activities with adaptations to be carried out at home under minimally controlled conditions could have a positive impact on student learning. In addition, it has been shown in previous studies that learning is not guaranteed only by transmitting information to the student (Duberman et al., 2015). Therefore, it is necessary to search for strategies that generate an experiential experience for a better acquisition of skills in the discipline. The modifications in the educational plan of the courses that involves practical activities, has allowed to improve the conceptual understanding, through the observations in the improvement of the acquisition of competences associated with the laboratory practices (Ben-Hur et al., 2017)

\section{Conclusions}

Currently, the context of virtual education demands educational strategies that allow meaningful learning and accurately assess in students the level of skills for solving problems. In the sense the appropriate use of remote laboratories, accompanied by the development of experiments at home, can 
facilitate the implementation of hybrid learning in courses that include laboratories providing the flexibility for the student to learn in any context. This educational tool can be implemented in various types of laboratories in different types of courses, helping to improve the experience of students and is part of the future of science education. Based on the results obtained from the student's surveys, we can conclude that the strategy proposed for the development of the course given to the migration of the virtual platform was successful, since it could be observed that the students managed to acquire the basic knowledge and the experimental capacities demanded for the course. It is also necessary to take into account the observations made by the students in order to propose a better strategy for implementation in future school cycles that are also under the same scheme of study. 


\section{Figures}

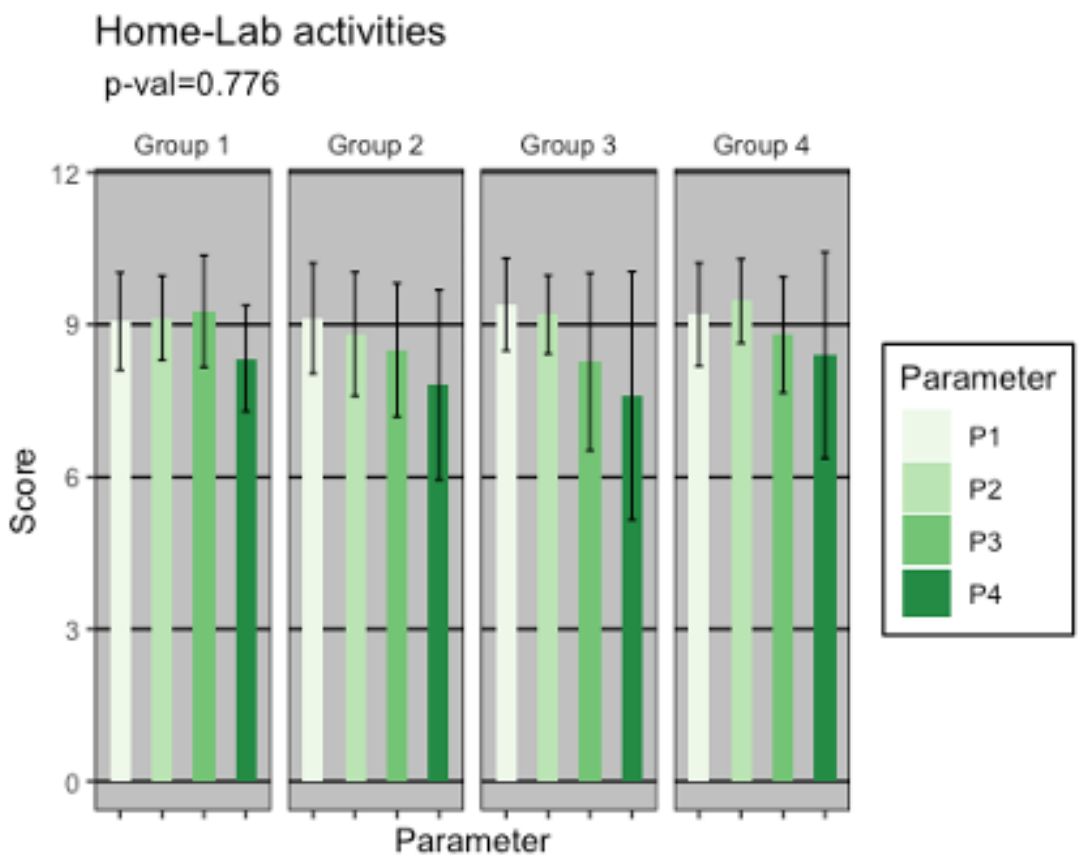

Figure 1. Evaluation of the parameters associated with the understanding of the fundamental concepts of microbiology. P1, concept of sterility and disinfection; $P 2$, preparation of culture media; $P 3$, isolation of microorganisms; P4, macroscopic structures.

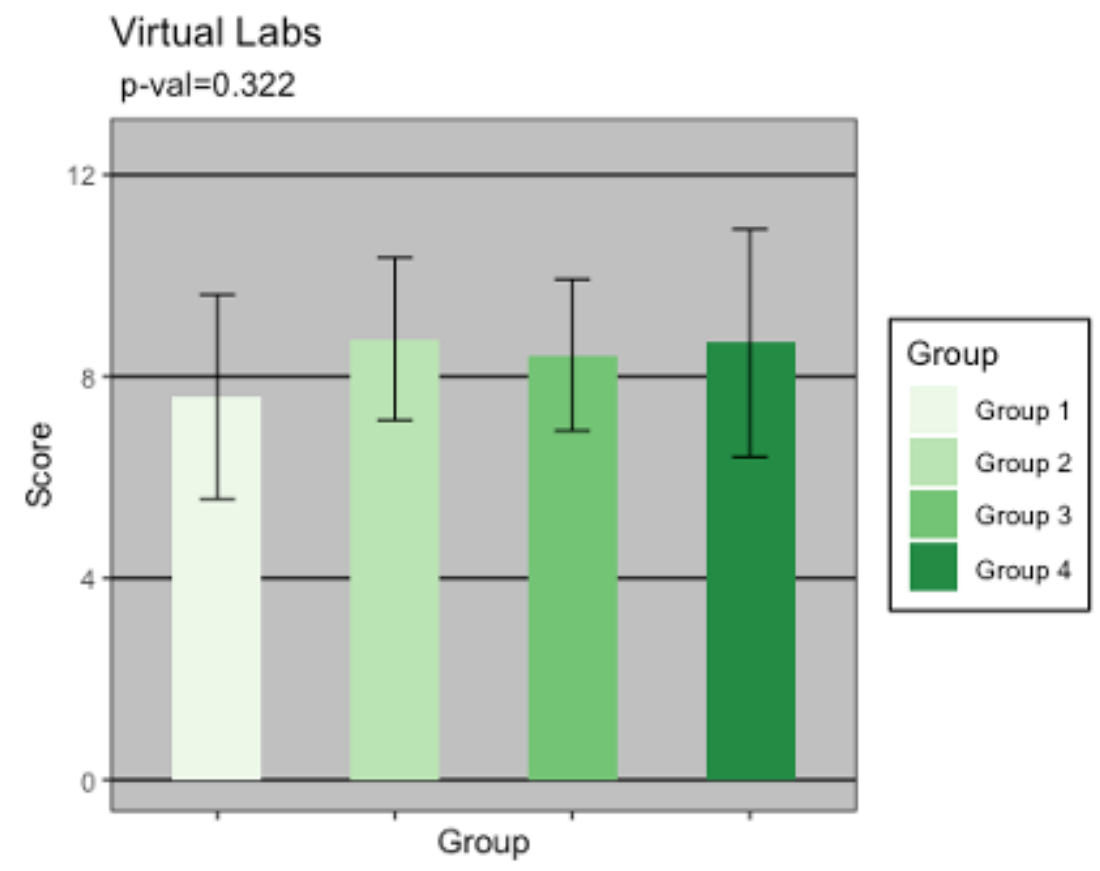

Figure 2. Evaluation of parameter 5, use of virtual laboratories simulators as support to understand the topics of the course in the groups implemented. 


\section{Course concepts comprexhension}

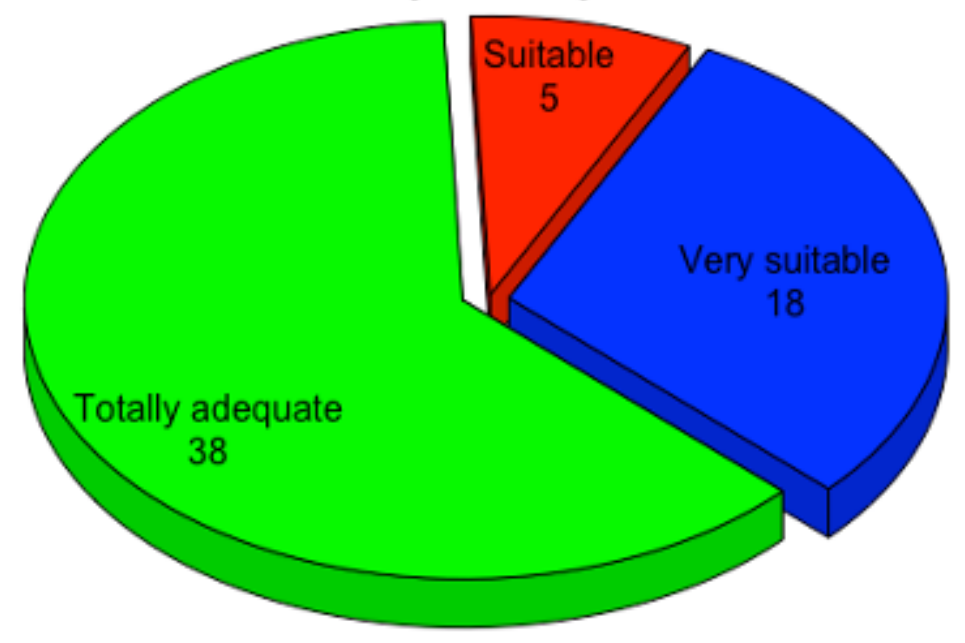

Figure 3. Evaluation of the level of satisfaction with the implementation of the laboratory activities developed at home.

\section{Tables}

Table 1. Results obtained from the analysis of variance and Tukey test between the groups evaluated with the respective criteria analyzed.

\begin{tabular}{ll}
\hline Evaluation & P-val \\
\hline Group & 0.209 \\
\hline Parameter & $5.23^{\wedge}-04$ \\
\hline Group:parameter & 0.727 \\
\hline Group 1-Group 2 & 0.387 \\
\hline Group 1-Group 3 & 0.535 \\
\hline Group 1-Group 4 & 0.999 \\
\hline Group 2-Group 3 & 0.996 \\
\hline Group 2-Group 4 & 0.349 \\
\hline Group 3-Group 4 & 0.493 \\
\hline
\end{tabular}


Table 2. Summary of opinions on the implementation of experimental activities at home.

\begin{tabular}{|l|l|}
\hline $\begin{array}{l}\text { Characteristics/ situations that you liked during } \\
\text { the development of the project at home }\end{array}$ & $\begin{array}{l}\text { Characteristics/ situations that you did not like } \\
\text { during the development of the project at home }\end{array}$ \\
\hline $\begin{array}{l}\text { “... your family can help you, if you can do it } \\
\text { with the equipment at home, you will probably } \\
\text { do it in the laboratory" }\end{array}$ & $\begin{array}{l}\text { “.. i did not have the necessary material and it is } \\
\text { difficult to work when we are in a non-optimal } \\
\text { space" }\end{array}$ \\
\hline $\begin{array}{l}\text { “... i had no idea that a bacterial isolation could } \\
\text { be made at home and also with homemade } \\
\text { materials" }\end{array}$ & $\begin{array}{l}\text { “... difficulty to get certain materials, setbacks } \\
\text { doing the lab activities" }\end{array}$ \\
\hline $\begin{array}{l}\text { “... the experimentation and the challenge } \\
\text { related with this, makes you try harder and that } \\
\text { teach us a lot" }\end{array}$ & “... lack of time and our lack of preparation" \\
\hline
\end{tabular}

\section{References}

Burga, E. (2004). Los procesos de aprendizaje en la formación docente: una mirada desde el Nuevo Enfoque Pedagógico y la interculturalidad. Lima: PROEDUCA https://repositorio.minedu.gob.pe/handle/20.500.12799/97

Ben-Hur .S. Neves, C. Altermann, R. Gonçalves, M.V. Lara, P.B. Mello-Carpes. (2017). Home-based vs. laboratory-based practical activities in the learning of human physiology: the perception of students, Adv. Physiol. Educ. 41 89-93. DOI: 10.1152/advan.00018.2016

Díaz-Barriga, F. \& Hernández-Rojas, G. (2010). Estrategias docentes para un aprendizaje significativo: una interpretación constructivista. México: McGraw-Hill. https://buo.org.mx/assets/diaz-barriga\%2C---estrategias-docentes-para-un-aprendizaje-

significativo.pdf

Duberman T, Mulford G, Bloom L.(2015). Learning by Doing Developing Physician Leaders $\begin{array}{lllll}\text { Through Action. } & \text { Physician } & \text { 2eadersh } 37 \text {. }\end{array}$ https://www.semanticscholar.org/paper/LEARNING-BY-DOING\%3A-DEVELOPING-

PHYSICIAN-LEADERS-Duberman-Mulford/28cc1e21137a61fb771534c6a918dad1b9662643

Hernández, J.S., Tobón, S. \& Vázquez, J. M. (2015). Estudio del liderazgo Socioformativo mediante la cartografía conceptual. Revista Iberoamericana de evaluación educativa, 8(2), 105-128. https://www.mendeley.com/catalogue/105bd083-9ab1-37ef-96f8-f570085f8e02/

Loan-Clark, J. \& Preston, D. (2002). Tensions and Benefits in collaborative research involving a university and another organization. Studies in Higher Education, 27(2), 169-185. https://doi.org/10.1080/03075070220120001

Martínez-Narváez, J. (2008). La teoría del aprendizaje y desarrollo de Vigotsky. Revista de innovación pedagógica y curricular. Recuperado de https://innovemos.wordpress.com/2008/03/03/lateoria-del-aprendizaje-y-desarrollo-de-vygotsky/

Rojas-Treviño, A. (2011). Conceptos y práctica de microbiología general. Palmira: Universidad Nacional de Colombia Facultad de Ciencias Agropecuarias. https://repositorio.unal.edu.co/handle/unal/8391

Vázquez-Antonio, J. M., Hernández-Mosqueda, J. S., Juárez Hernández, L. G., \& Guzmán-Calderón, C. E. (2017). El trabajo colaborativo y la socioformación: un camino hacia el conocimiento complejo. Educación Y Humanismo, 19(33), 334-356. https://doi.org/10.17081/eduhum.19.33.2648

Dhawan, S. (2020). Online Learning: A Panacea in the Time of COVID-19 Crisis. Journal of Educational Technology Systems, 49(1), 5-22. https://doi.org/10.1177/0047239520934018 
Noel, T. C., Rubin, J. E., Acebo Guerrero, Y., Davis, M. C., Dietz, H., Libertucci, J., \& Sukdeo, N. (2020). Keeping the microbiology lab alive: essential microbiology lab skill development in the wake of COVID-19. Canadian journal of microbiology, 66(10), 603-604. https://doi.org/10.1139/cjm2020-0373 